\title{
Feasibility of Potato Farming with Ex Vitro and Non Ex Vitro Seeds in the Batur District, Banjarnegara Regency
}

\author{
Nur Rahmawati ${ }^{1, *}$, Lestari Rahayu ${ }^{1}$, Yulia Rizqiana ${ }^{1}$ \\ ${ }^{I}$ Department of Agribusiness Universitas Muhammadiyah Yogyakarta, Indonesia \\ "Corresponding author. Email: rahma_wati_mf@umy.ac.id
}

\begin{abstract}
This study aims to determine the structure of production costs, revenue, profits, and feasibility of farming of potato farmers using ex vitro and non ex vitro seeds in Batur District, Banjarnegara Regency. The location of the study was determined purposive and sampling of farmers using ex vitro seeds was carried out using a census method of 30 farmers while farmers who used non ex vitro seeds used a proportional random sampling method of 30 farmers. The analysis used is descriptive analysis and t-test. The results showed that potato farming in 1 hectare of land was seen from the cost, income, and profit of farmers who used ex vitro seeds needed the cost of production of Rp. 20719651 obtain an income of Rp. 86299981 and a profit of Rp. 83085090. Whereas farmers who use non ex vitro seeds need a production cost of Rp. 2728906 obtain an income of Rp. 76315583 and a profit of Rp. 72187874. Based on the feasibility analysis seen from the R/C, capital productivity, labor productivity and capital productivity, potato farming with ex vitro seeds has a higher feasibility value than potato farming with non ex vitro seeds.
\end{abstract}

Keywords: ex vitro, feasibility, potatoes, profitability, seeds

\section{INTRODUCTION}

Potatoes have prospects in supporting the diversification of food and raw material industries. Potato needs tend to experience an increase along with population growth and public awareness of the importance of nutrition for health. This increase in potato production occurs due to the development of better production technology and farming management.

Central Java is one of the four potato growing centers in Indonesia. In its development from 2012 to 2016, productivity, production levels and harvested area of potato crops in Central Java province showed an upward trend [1], but if further studied the development of potato productivity from 2012 to 2016 in Central Java province could be said still low, this is because potato cultivation does not meet the standard operating procedures (SOP), potato productivity should range from 20 tons per hectare. However, the productivity of potatoes produced annually in Central Java Province is still low at 15 to 18 tons per hectare. This can be caused by the condition of the land which is increasingly damaged due to excessive use of pesticides and drugs and the low quality of seeds used. This is in line with the conditions that occur at the farm level. For example, potato farmers in the Dieng region have decreased potato productivity to $15-25$ tons/ha. In fact, in the 1990s the yield could reach 30-40 tons/ha [2].

This is a problem that many potato farmers still face in other areas, such as potato farmers in Batur District. This is due to the increasingly high price of potato seeds, and the low quality of seeds, so farmers prefer to use potato seeds from previous harvests, which results in low potato productivity. This situation also occurs in Kenya where farmers lack superior potato seeds so farmers depend on stored seeds from crops [3]. Meanwhile, the constraints faced by farmers in Solok District, namely the difficulty of getting potato seeds and the price of superior potato seeds tend to be expensive compared to the price of ordinary potatoes.

To increase the availability of superior seeds, a technology is needed that encourages increased seed production and potato crop productivity among other with aeroponics technique was introduced to enhance production of prebasic seeds from tissue culture plantlets [4], which is by innovating technology using ex vitro seeds. Ex vitro seeds are seeds produced from engineering technology to supply quality potato seeds through ex vitro tissue culture techniques. This technique can provide micro tuber and micro cuttings that are pathogen free, uniform (plant character), and not dependent on the season [5]. Ex vitro plant propagation results in a higher number of primary 
roots being initiated and having a percentage of live seedlings of $70 \%$ [6]. In addition, in the application of ex vitro techniques can be used as an alternative in the supply of plant seeds in large quantities [7]. With the development of technology, some farmers switched from non-ex-vitro seeds to potato farming systems using ex vitro seeds. This is done so that farmers get superior potato seeds, cheaper and quality costs for potato seeds so that the potato productivity is high.

The development of agricultural technology is always done to increase productivity, one of which is using ex vitro seeds. The use of technology can increase production and productivity. The productivity of potatoes using ex vitro seeds is higher than using non ex vitro seeds. In 2015, the Agency for the Assessment and Application of Technology (BPPT), sought to increase the productivity of potatoes which is high by applying ex vitro seeds in several regions in Indonesia such as Batu City and Banjarnegara Regency. Both of these regions prove that this technology can be used by surrounding farmers in propagating seedlings more easily, quickly and farmers get good quality seeds. With the use of quality seeds and appropriate management will affect the amount of production which will increase twice [8].However, until now, there are still many farmers who have not used ex vitro seeds on the farming that has been carried out. This is because the farmer thinks that by applying the cropping pattern by using non ex vitro seeds it is already profitable. Whereas by switching to using ex vitro seeds, of course it will require a considerable investment cost and very little understanding of the community regarding technology makes farmers tend to imitate farming methods that are profitable and easy to apply. If the application is difficult and the benefits do not differ significantly, making it difficult for farmers to switch to using ex vitro seeds.

Various studies have been conducted on the feasibility of potato farming, such as a study conducted by Suhartini (2016) regarding potato farming that uses certified seeds and uses non-certified seeds. Research on the technical efficiency of potato farming was carried out by [10]. The Research Socio-economic Feasibility of Potato Cultivation in Andhra Pradesh, India [11] Research on the analyses seed potato utilization pattern and its impact on farmers' profitability in Karnataka [12]. Research on the constraints and possible solutions for enhancing potato cultivation in India in general and Bihar in particular [13]. Research on the feasibility of farming potatoes with ex vitro seeds and non ex vitro seeds, especially in Banjarnegara Regency, has not been carried out by other researchers, so this study aims to analyze the costs of production, income, and feasibility of potato farming to farmers who use ex vitro seeds and farmers which uses non ex vitro seeds in Batur District, Banjarnegara Regency.

\section{METHODS}

The study used a purposive method with the consideration that Batur Subdistrict Banjarngara District is one of the centers of potato production in Central Java. 60 respondents consisting of 30 potato farmers with ex vitro seeds were determined by the census method and 30 farmer respondents who used non ex vitro seeds which were determined proportional random sampling.

The data analysis technique used was descriptive which included analysis of the costs of production, revenue, income, and profits on potato farming with ex vitro seeds and non ex vitro seeds. While the feasibility of potato farming is seen from the $\mathrm{R} / \mathrm{C}$, capital productivity, labor productivity and land productivity. The results of the calculation of total costs, revenues and profits are tested using the average difference test, namely the independent $t$ test.

\section{RESULTS AND DISCUSSION}

\section{A. Analysis Potato Farming}

Motivation Components of potato farming both ex vitro and non ex vitro consist of costs, admission, revenues, and profits. Costs consist of seeds, cocopeat, fertilizers, pesticides, depreciation of tools, labor and other costs. Data collection was carried out in December 2018 and analyzed on an area of 1 hectare per planting season.

The explicit costs in Table 1 show that the costs that farmers must incur for potato farming with non ex vitro seeds are higher than those of ex vitro seeds. The highest explicit cost is seed costs. The cost of seed needs for farmers who use non ex vitro seeds is higher than farmers who use ex vitro seeds. This is due to the influence of the spacing and size of the seeds used. The closer the planting distance and the smaller the size of the seed used, the greater the need for potato seeds. While the lowest cost in explicit costs is the cost of using cocopeat, especially for farmers who use ex vitro seeds. The use of high seeds, the price is also expensive, causing costs to be incurred higher. In addition, potato farmers use seeds produced by farmers around their homes and farmers strongly believe that the seeds purchased are of good quality. Small scale farmers in developing countries always grow potatoes with seeds obtained through the informal seed system, which is obtained from neighbors or local markets. Informal seed bulbs often have poor quality, which significantly reduces potato production [14].

Potato farmers who apply the ex vitro method using quality seeds Seeds with this method produce healthy and strong seeds so that their use can be more efficient [15]. The cost of seed needs can be said to be cheaper than conventional because ex-vitro farmers only buy seeds in the form of plantlets where each plantlet contains 10 seeds at a price of Rp.30,000. The seeds are then transferred to the field. Potato seedlings can be taken cuttings once a week, up to 2 or 3 times. 
The biggest cost of using fertilizer is found in non ex vitro farmers compared to ex vitro farmers. The difference in costs in the use of fertilizers is because the majority of non ex vitro farmers fertilize 1 to 2 times in one planting season, whereas in ex vitro farmers only do it once, namely when applying basic fertilizer. The amount of fertilizer used in the ex vitro method is lower than the use of fertilizer in the conventional method because ex vitro farmers follow the rules and guidelines for cultivation techniques in accordance with the dosage recommended by the government. Whereas conventional farmers, use fertilizer based on the level of knowledge and experience of farmers. Therefore, the use of fertilizer is excessive, resulting in costs incurred by farmers in purchasing fertilizer to be large.Ada perbedaan komponen tenaga kerja luar keluarga yaitu pada petani yang menggunakan bibit ex vitro terdapat komponen tenaga kerja untuk pembibitan, walaupun demikian biaya tenaga kerja luar keluarga petani non ex vitro lebih besar dibanding dengan petani yang ex vitro.

Table 1. Analysis of Potato Farming With Ex Vitro and Non Ex Vitro Seeds in Batur District Banjarnegara

\begin{tabular}{|c|c|c|}
\hline Description & $\begin{array}{c}\text { Ex Vitro Seeds } \\
\text { (Rp) }\end{array}$ & $\begin{array}{l}\text { Non Ex Vitro } \\
\text { Seeds (Rp) }\end{array}$ \\
\hline \multicolumn{3}{|l|}{ Explicit Cost } \\
\hline Seeds & $5,401,608$ & $10,139,153$ \\
\hline Cocopeat & 32,100 & - \\
\hline Fertilizer & $2,803,834$ & $3,336,279$ \\
\hline Pesticide & $2,722,999$ & $3,463,000$ \\
\hline Depreciation & 974,105 & 202,635 \\
\hline $\begin{array}{c}\text { Outside } \\
\text { Labor }\end{array}$ & $3,354,629$ & $3,544,972$ \\
\hline \multirow[t]{2}{*}{ Other Cost } & $2,215,485$ & 2475408 \\
\hline & $17,504,760$ & $23,162,197$ \\
\hline \multicolumn{3}{|l|}{ Implicit Cost } \\
\hline Labor in the Family & 643,901 & 666,774 \\
\hline Own Land Rent & $1,993,333$ & $2,697,333$ \\
\hline $\begin{array}{ll}\text { Own } & \text { Capital } \\
\text { Interest }\end{array}$ & 577,657 & 764,352 \\
\hline & $3,214,891$ & $4,128,459$ \\
\hline Total Cost & $20,719,651$ & $27,289,906$ \\
\hline Revenue & $103,804,741$ & $99,477,780$ \\
\hline Income & $86,299,981$ & $76,315,583$ \\
\hline Profit & $83,085,090$ & $72,187,874$ \\
\hline $\begin{array}{ll}\text { Different } & \text { Test } \\
\text { Average } & \\
\end{array}$ & $\mathbf{T}_{\text {count }}$ & $T_{(59 ; 0,05)}$ \\
\hline Total Cost & 2.222 & 1.671 \\
\hline Income & 4.311 & 1.671 \\
\hline Profit & 4.226 & 1.671 \\
\hline
\end{tabular}

The low cost of using cocopeat is because this media is only used as a supporting material in the nursery process for farmers who use ex vitro seeds. Whereas farmers who use non ex vitro seeds do not need this cocopeat, because most farmers who use non-ex-vitro seeds get seeds from previous crops or buy from farmers.

The implicit costs incurred by farmers using non ex vitro seeds are higher than farmers who use ex vitro seeds. This is in line with research on organic rice and conventional rice which shows that the implicit costs of conventional farmers are greater than those of organic farmers in Bener District [16]. The biggest implicit cost is the cost of renting their own land, both to farmers who use ex vitro seeds and farmers who use non ex vitro seeds. The rental fee is influenced by the location of the land, the condition of the land in each sub-district with the level of rental costs.

The total costs incurred by farmers in farming potatoes with ex vitro seeds are Rp. 20719651 lower than with non ex vitro seeds of Rp. 27289906. This cost difference is reinforced by the $t$ test which is significant at the $5 \%$ error rate, meaning that the cost of potato farming with ex vitro seeds is smaller than the cost of farming with non ex vitro seeds. The results of this study are not in line with the results of research on farmers who use certified and noncertified seeds which show that the total cost of farmers using certified seeds is higher than non-certified. This is because the cost of purchasing seeds and the use of labor for farmers who use certified seeds is greater than noncertified [9]. The difference in the use of costs is also influenced by education, credit access, farm experience, degree of specialization and frequency of weeding [17]

Cash Revenue from ex vitro method of potato farming per planting season per hectare are higher compared to non ex vitro farmers. This is due to the higher productivity and price of the ex vitro potato method compared to non ex vitro farmers. The yields obtained by farmers both ex vitro and no ex vitro methods are partly set aside for re-seeding by farmers. In addition, farmers also sell potato seeds in addition to cash revenue.

Non cash revenue in the form of seeds stored by ex vitro farmers are higher than non ex vitro farmers. This difference is due to the higher production of potatoes in ex-vitro farmers so that farmers can set aside their crops to be used as seed again and can save on production costs.

Ex vitro method of potato farming income and profits are greater than the income of conventional farmers because the production and prices obtained are also high. Potato provides excellent opportunities in raising an income of the farmers as it has capacity to yield 5-10 times more than cereals, pulses or oilseeds [13]. Profit are also influenced by seed potato source, variety wise seed use rate, seed replacement rate, seed size, variety wise potato yield [12]. 


\section{B. Feasibility Of Potato Farming}

Feasibility analysis of potato farming both using seeds with ex vitro or with non ex vitro seeds, based on $\mathrm{R} / \mathrm{C}$, capital productivity, land productivity and labor productivity is very feasible. Farming potatoes with ex vitro seeds has a higher feasibility value than farming potatoes with non ex vitro (Table 2).

Table 2. Analysis Feasibility of Potato Farming in The Batur District Banjarnegara

\begin{tabular}{|c|c|c|}
\hline Description & $\begin{array}{l}\text { Ex Vitro } \\
\text { Seeds }\end{array}$ & $\begin{array}{l}\text { Non Ex } \\
\text { Vitro } \\
\text { Seeds } \\
\end{array}$ \\
\hline $\mathrm{R} / \mathrm{C}$ & 5.0 & 3.6 \\
\hline Capital productivity (\%) & 477 & 314 \\
\hline $\begin{array}{l}\text { Land } \\
(\mathrm{Rp} / \mathrm{ha})\end{array}$ & 85078423 & 74884457 \\
\hline Labor productivity & 4910791 & 3950862 \\
\hline
\end{tabular}

The feasibility value of potato farming with ex vitro seeds in Batur sub-district is higher than potato farming with certified potato seeds [9].

In addition, potato farming with new technology in the form of ex vitro seeds can provide a higher feasibility value than non ex vitro seeds. as well as the results of research on legowo jajar planting technology on rice farming also has a higher feasibility value than conventional [18].

\section{CONCLUSION}

The The results showed that potato farming in 1 hectare of land was seen from the cost, income, and successive advantages, farmers who used ex vitro seeds needed a production cost of Rp. 20719651 obtained an income of Rp. 86299981 and a profit of Rp. 83085090. Whereas farmers who use non ex vitro seeds need a production cost of Rp. 27289906 obtained an income of Rp. 76315583 and a profit of Rp. 72187874. Based on the results of the feasibility analysis seen from $\mathrm{R} / \mathrm{C}$, capital productivity, labor productivity and capital productivity shows that potato farming with ex vitro seeds has a higher feasibility value than potato farming with non ex vitro seeds.

The importance of the role of extension agents to open up farmers' perceptions of the advantages of ex vitro seeds economically so that the interest of farmers to use ex vitro seeds is high. In addition, the need to increase farmers' knowledge and skills regarding the use and application of ex vitro seeds more easily.

\section{REFERENCES}

[1] Departemen Pertanian, "Perkembangan Produktivitas, Produksi Dan Luas Lahan Tanaman Kentang Di Jawa Tengah Tahun 2012-2016," Kementrian Pertanian, 2018.
[2] I. Pertiwi, S. D. W. Prajanti, and Juhadi, "Strategi Adaptasi Petani Dalam Pengolahan Lahan Kering di Desa Dieng Kecamatan Kejajar Kabupaten Wonosobo," J. Educ. Soc. Stud., vol. 6, no. 2, pp. 87-91, 2017.

[3] J. Muthoni, H. Shimelis, and R. Melis, "Potato Production in Kenya: Farming Systems and Production Constraints," J. Agric. Sci., vol. 5, no. 5, 2013.

[4] J. Muthoni, M. Mbiyu, and J. N. Kabira, "Up-scaling production of certified potato seed tubers in Kenya: potential of aeroponics technology.," J. Hortic. For., vol. 3, no. 8, pp. 238-243, 2011.

[5] BPPT, "Teknologi Ex Vitro BPPT, Solusi Atas Permasalahan Bibit Kentang," Monday, 23 January 2017 09:11, 2017. .

[6] S. Amarillis, "Perbanyakan Tanaman Sagu ( Metroxylon spp.) Secara Ex Vitro (Di Persemaian Polybag Dan Rakit) Dan In Vitro Melalui Kultur Jaringan,” Bogor, 2013.

[7] Karyanti, Y. Sigit, T. Tajuddin, Erwinda, Minaldi, and N. Haska, "Penanganan Anakan Muda Pada Kultur Ex Vitro Untuk Mengasilkan Bibit Sagu ( Metroxylon sagu Rottb.) Siap Tanam," J. Bioteknol. Biosains Indones., vol. 3, no. 1, pp. 13-19, 2016.

[8] M. R. Shaheb, M. M. Begum, M. K. Ahmed, M. I. Nazrul, and S. G. Wiersema, "Challenges of Seed Potato (Solanum tuberosum L.) Production and Supply System in Bangladesh," Agric., vol. 13, no. 1,p. 173, 2016.

[9] A. Suhartini, "Analisis Pendapatan Usahatani Kentang Yang Menggunakan Benih Sertifikat dan Non Sertifikat Di Desa Girijaya Kecamatan Cikajang Kabupaten Garut,” Bogor, 2016.

[10] A. U. Andarwati, "Efisiensi Teknis Usahatani Kentang dan Faktor yang Mempengaruhi di Kecamatan Batur Kabupaten Banjarnegara,” Bogor, 2011.

[11] R. K. Rana, S. Arya, M. S. Kadian, B. P. Singh, R. Quiroz, and P. Monneveux, "Socio-economic Feasibility of Potato Cultivation in Andhra Pradesh, India," Potato Res., vol. 59, no. 2, pp. 167-179, 2016.

[12] R. K. Rana, N. Sharma, S. Arya, M. S. Kadian, and B. P. Singh, "Seed potato utilization pattern and its impact on farmers' profitability in Karnataka," Indian J. Agric. Res., vol. 47, no. 6, pp. 488-495, 
2013.

[13] T. Shankar, K. M. Singh, A. Kumar, and S. K. Singh, "Cultivation and Processing of Potato in Bihar: Issues and Strategies," vol. 32, no. 4B, pp. 1647-1652, 2014.

[14] S. Thomas-Sharma et al., "Seed degeneration in potato: The need for an integrated seed health strategy to mitigate the problem in developing countries," Plant Pathol., vol. 65, no. 1, pp. 3-16, 2016.

[15] M. M. Khalil, A. M. H. Abd El Aal, and M. M. Samy, "Growth Improvement of Potato Plants Produced from Tissue Culture," Middle East J. Agric. Res., vol. 5, no. 4, pp. 666-671, 2016.

[16] W. I. Azis, "Studi Komparatif Usahatani Padi Organik Dan Padi Konvensional Di Kecamatan Bener Kabupaten Purworejo,” Yogyakarta, 2017.

[17] M. M. Assa, A.-K. Edriss, and G. C. Matchaya, "Cost efficiency, Morishima, Allen-Uzawa and Cross-Price elasticities among Irish potato farmers in Dedza district, Malawi," Int. J. Econ. Sci. Appl. Res., vol. 6, no. 1, pp. 59-73, 2013.

[18] N. Rahmawati, A. Fauzi, and Triyono, "Kelayakan Usahatani Padi Menggunakan Sistem Tanam Jajar Legowo Di Kabupaten Bantul," in Prosiding Dukungan Teknologi Pertanian dan Sumberdaya Finansial dalam Usaha Mencapai Swasembada Pangan, 2016, pp. 1-20. 